\title{
Mesenchymal Stem Cell Applications in Spine Disorders: A Comprehensive Review
}

\author{
Alice Baroncini ${ }^{1,2, *}{ }^{\mathbb{D}}$, Jörg Eschweiler ${ }^{1, \dagger}{ }^{+}$Philipp Kobbe ${ }^{1}$, Valentin Quack ${ }^{1}$, Samir Smajic ${ }^{3}$, Per Trobisch ${ }^{2}$, \\ Frank Hildebrand ${ }^{1}$ and Filippo Migliorini ${ }^{1,+}$ \\ 1 Department of Orthopaedics, Trauma and Reconstructive Surgery, RWTH Aachen University, \\ 52074 Aachen, Germany; joeschweiler@ukaachen.de (J.E.); pkobbe@ukaachen.de (P.K.); \\ vquack@ukaachen.de (V.Q.); fhildebrand@ukaachen.de (F.H.); fmigliorini@ukaachen.de (F.M.) \\ 2 Department of Spine Surgery, Eifelklinik St. Brigida, 52152 Simmerath, Germany; per.trobisch@artemed.de \\ 3 Department of Orthopaedic and Trauma Surgery, St-Josef-Krankenhaus, 52441 Linnich, Germany; \\ samir.smajic@ct-west.de \\ * Correspondence: alice.baroncini@gmail.com; Tel.: +49-0241-80-35529 \\ + The authors equally contributed to the manuscript.
}

Citation: Baroncini, A.; Eschweiler, J.;

Kobbe, P.; Quack, V.; Smajic, S.;

Trobisch, P.; Hildebrand, F.;

Migliorini, F. Mesenchymal Stem Cell Applications in Spine Disorders: A Comprehensive Review. Appl. Sci. 2021, 11, 7966. https://doi.org/ 10.3390/app11177966

Academic Editor: Andrea Ballini

Received: 26 July 2021

Accepted: 25 August 2021

Published: 28 August 2021

Publisher's Note: MDPI stays neutral with regard to jurisdictional claims in published maps and institutional affiliations.

Copyright: (c) 2021 by the authors. Licensee MDPI, Basel, Switzerland. This article is an open access article distributed under the terms and conditions of the Creative Commons Attribution (CC BY) license (https:/ / creativecommons.org/licenses/by/ $4.0 /)$.
Featured Application: Current and potential applications of mesenchymal stem cells for the management of spine disorders.

Abstract: Mesenchymal stem cells (MSCs) are increasingly being employed in a number of orthopedic settings, in particular in the treatment of hip and knee osteoarthritis. Recently, the use MSCs has been investigated for different spine settings. However, the use of these cells is not yet widespread in the clinical practice. The aim of this review was to investigate the current literature regarding the use of MSCs in different spine conditions and discuss possible future applications. In particular, degenerative disc disease is the most studied field for MSC application, and is the only one that has already reached the clinical practice, albeit not routinely. Spinal cord injuries are another extensively investigated use of MSCs: despite encouraging preliminary results, a consensus on the efficacy of stem cell therapy for spinal cord injuries has not yet been reached, and their use is still only experimental.

Keywords: spine; degenerative disc disease; Spinal Cord Injury; mesenchymal stem cells

\section{Introduction}

Mesenchymal stem cells (MSCs) are increasingly being investigated in a number of different musculoskeletal conditions. MSCs have been investigated for osteoarthritis and chondral defects of the knee, ankle, and hip joints [1-5]. Similarly, MSCs have also been considered for the prevention and management of non-union or critical bone defects, but the data are not yet sufficient to determine their efficacy in these settings [6-8]. Recently, a growing interest for MSC application in spine disorders has been reported. Evidence on this topic is still limited. Previous studies have focused on intradiscal injections of MSCs for degenerative disc disease or for the treatment of spinal cord injuries $[9,10]$. The present review investigated the current available evidence, discussing pitfalls and future frontiers of MSC applications in spine settings.

\section{Intradiscal Injections}

Degeneration of the intervertebral disc is a common process which may lead to disability and lower back pain [11]. The socioeconomic burden caused by lower back pain is considerable, as this is the musculoskeletal disorder causing the highest health care expenditures [12]. The standard of care is represented by pharmacological, physical, and infiltrative therapy, followed by surgery when the symptoms cannot be controlled or neurological deficits arise [9,13-15]. However, available therapies are prone to side effects and 
complications, increasing the demand for new management options [9]. Intervertebral disc degeneration is accompanied by a quantitative and qualitative degeneration of the nucleus pulposus, along with an alteration of the biomechanics and homeostatic processes $[9,16]$. MSCs are believed to promote cell differentiation and chemotaxis and to modulate the immune reaction to reduce pain and disabilities related to discal degeneration.

\subsection{Clinical Outcomes}

Eleven original studies on the intradiscal injection of MSCs are currently available: two randomized control trials (RCTs), eight prospective studies, and one retrospective study. One study was conducted on patients who previously underwent discectomy at the treated level [17]. All other investigations only included patients with a history of chronic lower back pain and clinical findings consistent with discogenic origin of the symptoms, with failed conservative therapy and no previous surgeries at the level of the treated disc [18-25]. A summary of the included articles is presented in Table 1.

In 2006, Haufe and Mork [17] published the first prospective study on 10 patients (5 males and 5 females, aged 32-74 years) who underwent intradiscal injections of hematopoietic stem cells (HSCs) for discogenic back pain. All of the included patients had previously undergone endoscopic discectomy. The HSCs were obtained from the iliac crest (bone marrow aspirate), and $1 \mathrm{~mL}$ of HSCs was injected into the problematic disc. The treatment was followed by 2 weeks of hyperbaric oxygen therapy to improve the oxygen content of the disc space, which is known to be a district with limited blood flow. At a 12-month follow-up, none of the patients experienced an improvement of pain measured with the visual analogic scale (VAS), and $90 \%$ of the subjects proceeded with surgical treatment. The negative outcomes obtained by Haufe and Mork potentially resided in the patient selection; all of the treated individuals underwent discectomy prior to treatment, which may have impaired the results. In fact, MSCs are not capable of recreating the nucleus pulposus once this has been extruded (e.g., due to herniation) or surgically removed, as was the case in the presented cohort [9]. Recently a retrospective study by Wolff et al. was published [18], reporting the results of intradiscal bone marrow-derived MSC transplantation in 33 patients (19 men, 14 women, mean age of 45 years) suffering from lower back pain. At a 52-week follow-up, positive outcomes in terms of pain and disability were observed; $39 \%$ of the patients had an improvement in the VAS of at least 50\%, and 31\% reported an improvement of at least 50\% in the Oswestry Disability Index (ODI). The results of seven prospective studies have been analyzed in a recent meta-analysis [9]. The study included one RCT [23] and six prospective studies [20-22,24-26]. The meta-analysis investigated data obtained from 98 patients with a mean age of 44 years. The MSCs were obtained from bone marrow aspirate in most studies, while Kumar et al. [20] performed transplantation from adipose derived stem cells. Pettine et al. performed transplantation of centrifuged bone marrow aspirate [26], while all other authors performed a culture of the harvested cells before reinjection. Overall, significant improvements in both disability and pain scores were observed at a 1-year follow-up, with the ODI improving by $21 \%$ and the VAS by $30 \%$. Pettine et al. [19] successively published the 3-year follow-up of the cohort presented in 2015. At this time point, the authors observed a significant improvement in the ODI and VAS scores compared with the baseline. Six out of 26 patients underwent surgery, but only one of them reported an improvement in the clinical and functional situation in comparison with the baseline at the beginning of the study. Recently, Amirdelfan et al. published the results of an RCT comparing the outcomes of the injection of different amounts of allogenic, in vitro expanded MSCs (6 and 18 million) with hyaluronic acid (HA), with the outcomes obtained with HA alone or a saline solution [11]. Of the 100 involved subjects, those in the saline solution arm presented a higher rate of necessity for post-treatment intervention than patients in the 18 million MSCs group. The 18 million MSCs group scored best in terms of the VAS and ODI at all follow-ups (12, 24, and 36 months), obtaining results better than the other treatment arms (6 million MSCs and HA). However, no significant radiographic improvement was observed in any of the studied cohorts. 


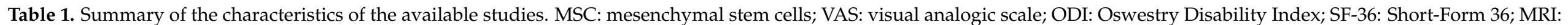
magnetic resonance imaging; CT: computed tomography.

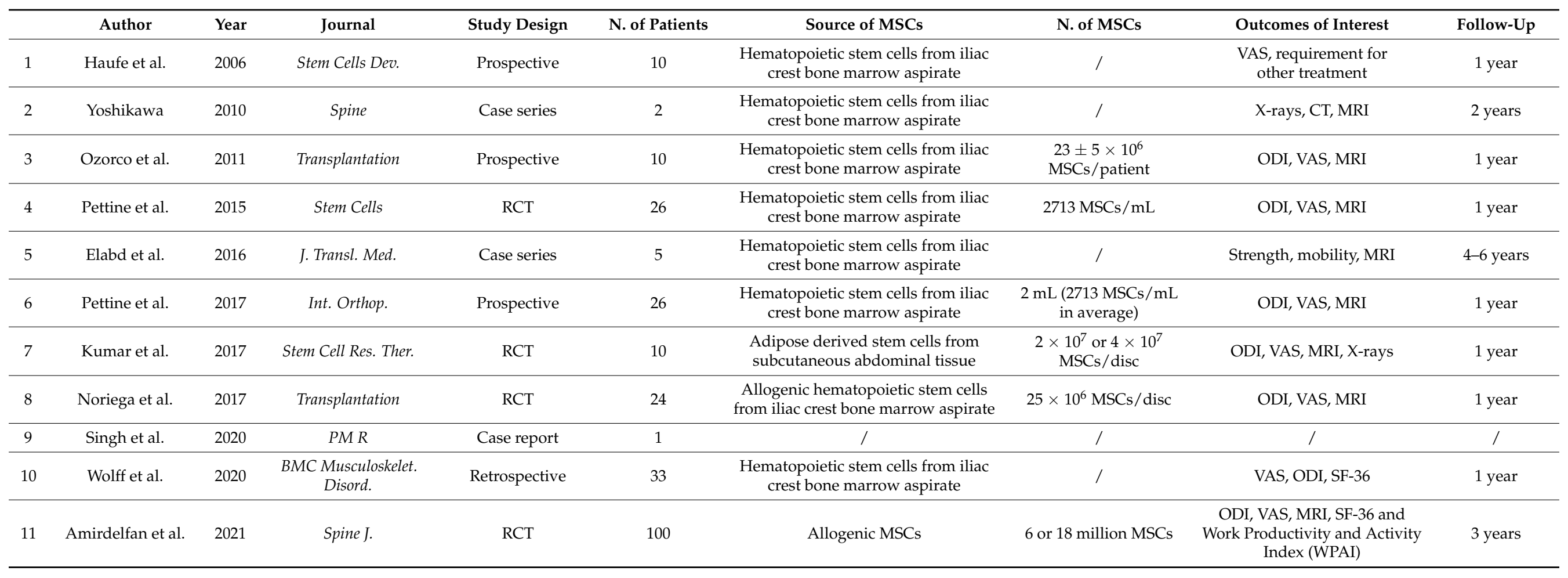




\subsection{Safety and Complications}

The analysis of safety and complications represents a key step when investigating a new therapeutical option. While all of the aforementioned studies reported on complications and adverse events, most authors did not observe any major adverse event correlated to the intervention [18-25]. Three studies reported that a small number of patients experienced lower back pain after the treatment, which either resolved spontaneously or required pharmacological management $[19,21,23]$. Amirelfan et al. reported discontinuation of the study due to severe pain in 3 out 100 patients, along with one case of infection at the transplantation site [21]. Centeno et al. observed one case of disc herniation in their cohort of 33 patients [21]. Singh et al. reported one case of osteomyelitis and discitis following intradiscal stem cell injection; however, the transplantation procedure had been performed at another institution, and no details were available [27]. Due to the multipotent nature of stem cells, safety concerns exist regarding the possibility that these cells may potentially undergo uncontrolled proliferation or differentiation and thus initiate osteophyte formation [28] or tumorous processes [29,30]. While there are no reports concerning the tumorigenesis potential following the use of stem cells in for orthopedic conditions in the literature, one case of glial hyperplasia has been observed [31]. The patient noticed progressive weakness in the lower limbs accompanied by increasing pain two years after he underwent two intradiscal MSCs injections at two different institutions in Mexico and Russia. No data are available regarding the procedures. The subject underwent a laminectomy and the implantation of an expansile duraplasty without improvement of the symptoms. The patient was known to suffer from multiple autoimmune diseases prior to the MSC transplantation. As no data on the procedure or the kind of stem cells used are available, it is not possible to draw conclusions on the correlation between injection, autoimmune diseases, and the development of glial hyperplasia. It is also possible that the MSCs may have been inadvertently injected intrathecally, as this case resembles a similar complication reported by Hurst after intrathecal MSC administration [32]. This complication highlighted the fact that serious complications are possible, although rare, and particular consideration should be taken when considering MSC management for patients with systemic chronic conditions that may influence the behavior of the cells per se.

\subsection{Current Guidelines}

Two guidelines have recently been published to aid physicians considering stem cell treatment for chronic lower back pain [16,33]. Based on the available literature, the level of evidence for the use of MSCs in lumbar discogenic lower back pain has been assessed as III [16]. MSCs in musculoskeletal disorders-including spine conditions-have shown to fulfill the criteria of minimal manipulation and homologous use required by national and international regulatory agencies for cell therapy use [33]. Overall, these two criteria require that the processing of the tissue or cells does not alter the relevant characteristics of said tissue or cells, and that recipient tissue or cells exert similar basic functions as the tissue or cells in the donor, respectively. There is also strong evidence that MSC injection is a safe procedure when performed by a trained physician and under sterile conditions and adequate imaging [33].

\section{Spinal Cord Injuries}

The management of spinal cord injuries (SCIs) represents a challenge, as patients and physicians are confronted with numerous issues ranging from sensory and motor impairment to bed sores [34]. It is estimated that anywhere from 300,000 to 1 million people currently live with chronic SCIs [35,36], and it is thus of paramount importance to investigate possible treatment options to limit the damage to the neural structures after trauma and improve the patients' quality of life after chronic damage has set in [34]. The rationale in the use of MSCs for the treatment of SCIs lies in the known ability of these cells to regenerate damaged nervous tissue [37-39] and in the possibility of these cells to act as scaffold for the regeneration of the lost nervous tissue $[40,41]$. The stem cells are delivered 
intravenously, intraparenchymally, or intrathecally, with or without the use of scaffolds and adjuvants or anti-inflammatory drugs such as minocycline [34,39].

Most available data regard animal studies [42], and the clinical data currently present in the literature are very limited. Recently, seven clinical studies regarding the use of MSCs in patients affected by spinal cord injuries have been published. One clinical trial on four patients with thoracic SCIs treated with midline bilateral human spinal cord-derived neural stem cell injection showed some degree of sensory and motor improvement without any reported adverse events [43]. Two further SCI patients observed a sensory and functional improvement one year after transplantation of MSCs on a collagen scaffold at the injury site [44]. Vaquero et al. reported the results obtained for nine SCI patients treated with intrathecal MSC administration, with an improvement in sensitivity and motor control without any adverse events [45]. In one case report, a patient with an SCI following atlantooccipital subluxation was treated with intrathecal MSCs harvested from the iliac crest. In this case, no clinical or radiological improvement could be observed [46]. Two further studies assessed the safety and feasibility of MSC therapy for SCIs [47,48], but one was discontinued as the obtained results did not prove sufficient clinical efficacy [47]. A recent meta-analysis established that MSC treatment can improve impairment, sensory scores, and electrophysiological parameters without causing major adverse events [10]. While the data from the available studies are encouraging, there is no consensus on the ideal way to administer MSCs in SCI patients, and the evidence for the effectiveness of this therapeutic approach is still lacking. Currently, 14 clinical trials on the use of MSCs for SCIs are registered on clinicaltrials.gov and will hopefully offer new insight on this topic (status: recruiting).

The key information regarding the available studies is presented in Table 2. 


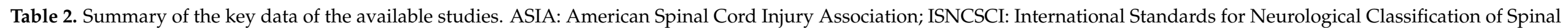
Cord Injury.

\begin{tabular}{|c|c|c|c|c|c|c|c|c|c|c|}
\hline & Author & Year & Journal & Study Design & N. of Patients & Source of MSCs & MSCs Administration & N. of MSCs & Outcomes of Interest & Follow-Up \\
\hline 1 & Chotivichit et al. & 2015 & J. Med. Case Rep & Case report & 1 & $\begin{array}{l}\text { Bone marrow derived } \\
\text { mesenchymal stem cells } \\
\text { from iliac crest }\end{array}$ & Intrathecal & $30 \times 10^{6}$ & ASIA Score, MRI & 12 months \\
\hline 2 & Curtis et al. & 2018 & Cell Stem Cell & Phase 1 clinical trial & 4 & $\begin{array}{l}\text { Human spinal cord } \\
\text { derived neural stem cell } \\
\text { (NSI-566) }\end{array}$ & Stereotactic injection & / & $\begin{array}{l}\text { ISNCSCI motor and } \\
\text { sensory scores, MRI }\end{array}$ & 18-27 months \\
\hline 3 & Xiao et al. & 2018 & Cell Transplant & $\begin{array}{c}\text { Prospective Case } \\
\text { Series } \\
\end{array}$ & 2 & $\begin{array}{l}\text { Umbilical cord MSCs on } \\
\text { bovine scaffold }\end{array}$ & $\begin{array}{l}\text { Surgical graft into the } \\
\text { spinal cord defect }\end{array}$ & $4 \times 10^{7}$ & $\begin{array}{l}\text { ASIA Score, MRI and } \\
\text { nerve electrophysiology }\end{array}$ & 12 months \\
\hline 4 & Vaquero et al. & 2018 & Cytotherapy & Phase 2 clinical trial & 11 & $\begin{array}{l}\text { Autologous MSCs from } \\
\text { peripheral blood }\end{array}$ & Intrathecal & $100 \times 10^{6}$ & $\begin{array}{c}\text { ASIA Score, VAS, } \\
\text { urodynamic and } \\
\text { neurophysiological study }\end{array}$ & 4 months \\
\hline 5 & Levi et al. & 2018 & Neurosurgery & Prospective & 29 & $\begin{array}{l}\text { Human central nervous } \\
\text { system stem cells }\end{array}$ & $\begin{array}{l}\text { Intramedullary } \\
\text { perilesional } \\
\text { transplantation }\end{array}$ & 20-40 million & MRI & 12 months \\
\hline 6 & Levi et al. & 2019 & J. Neurotrauma & Phase 2 clinical trial & 12 & $\begin{array}{l}\text { Human central nervous } \\
\text { system stem cells }\end{array}$ & $\begin{array}{l}\text { Intramedullary } \\
\text { perilesional } \\
\text { transplantation }\end{array}$ & 40 million & $\begin{array}{l}\text { ISNCSCI, MRI, pain } \\
\text { evaluation }\end{array}$ & 24 months \\
\hline
\end{tabular}




\section{Future Perspectives}

Given the increased demand of MSC therapy for spine conditions, the number of preclinical and clinical investigations is exponentially growing. Regarding the management of degenerative conditions, such as intervertebral disc degeneration, the implementation of office-based systems is appealing both for patients and physicians [49], as it may lead to reduction of the discomfort and burden related to hospitalization. This may make MSC management available for a larger number of subjects. Platelet-rich plasma (PRP) has been implemented with positive outcomes for other degenerative spine conditions (e.g., facet joint osteoarthritis) and has been investigated for facet joint, epidural, and sacroiliac joint injections [16]. While the quality of the recommendations for these applications is limited and thus not yet conclusive [16], these may pave the road for the development of MSC injections for spine ailments. Another possible development for intervertebral disc disease may be represented by MSC-derived extracellular vesicles, which seem to modulate inflammation while inducing cellular proliferation and extracellular matrix production [50]. Furthermore, the use of MSCs may be implemented to support spinal fusion surgery and prevent pseudoarthrosis. This complication is developed by $1-2 \%$ of patients undergoing spine fusion [51], and these subjects often require revision surgery. Furthermore, MSCs may help improve fusion in stand-alone anterior cervical or lumbar implants [52]. Multiple studies have been conducted to prove that MSCs can induce spinal fusion in animal models [39], and hopefully they will lead the way for future clinical studies.

\section{Conclusions}

Intradiscal injection of MSCs for degenerative disc ailments is gaining growing interest and broad research. SCIs represent another field in which MSCs have been demonstrated to be a resource to improve clinical outcomes. MSCs are currently investigated mainly in preclinical settings, and their use has not yet become common in clinical practice.

Author Contributions: Conceptualization A.B. and F.M.; methodology, A.B., F.M. and J.E.; writingoriginal draft preparation, A.B., F.M. and J.E.; writing - review and editing, P.K., V.Q., F.H., S.S. and P.T. All authors have read and agreed to the published version of the manuscript.

Funding: This research received no external funding.

Institutional Review Board Statement: Not required.

Informed Consent Statement: Not applicable.

Data Availability Statement: Not applicable.

Conflicts of Interest: A.B., J.E., P.K., V.Q., F.H., S.S., F.M.: none. P.T.: Globus Medical and Zimmer Biomet (personal fees). The funders had no role in the design of the study; in the collection, analyses, or interpretation of data; in the writing of the manuscript, or in the decision to publish the results.

\section{References}

1. Wiggers, T.G.; Winters, M.; van den Boom, N.A.; Haisma, H.J.; Moen, M.H. Autologous stem cell therapy in knee osteoarthritis: A systematic review of randomised controlled trials. Br. J. Sports Med. 2021. [CrossRef] [PubMed]

2. Tan, S.H.S.; Kwan, Y.T.; Neo, W.J.; Chong, J.Y.; Kuek, T.Y.J.; See, J.Z.F.; Wong, K.L.; Toh, W.S.; Hui, J.H.P. Intra-articular Injections of Mesenchymal Stem Cells Without Adjuvant Therapies for Knee Osteoarthritis: A Systematic Review and Meta-analysis. Am. J. Sports Med. 2021, 363546520981704. [CrossRef]

3. Maheshwer, B.; Polce, E.M.; Paul, K.; Williams, B.T.; Wolfson, T.S.; Yanke, A.; Verma, N.N.; Cole, B.J.; Chahla, J. Regenerative Potential of Mesenchymal Stem Cells for the Treatment of Knee Osteoarthritis and Chondral Defects: A Systematic Review and Meta-analysis. Arthroscopy 2021, 37, 362-378. [CrossRef] [PubMed]

4. Melick, G.; Hayman, N.; Landsman, A.S. Mesenchymal Stem Cell Applications for Joints in the Foot and Ankle. Clin. Podiatr. Med. Surg. 2018, 35, 323-330. [CrossRef]

5. McIntyre, J.A.; Jones, I.A.; Han, B.; Vangsness, C.T. Intra-articular Mesenchymal Stem Cell Therapy for the Human Joint: A Systematic Review. Am. J. Sports Med. 2018, 46, 3550-3563. [CrossRef]

6. Killington, K.; Mafi, R.; Mafi, P.; Khan, W.S. A Systematic Review of Clinical Studies Investigating Mesenchymal Stem Cells for Fracture Non-Union and Bone Defects. Curr. Stem Cell Res. Ther. 2018, 13, 284-291. [CrossRef] 
7. Freitas, J.; Santos, S.G.; Gonçalves, R.M.; Teixeira, J.H.; Barbosa, M.A.; Almeida, M.I. Genetically Engineered-MSC Therapies for Non-unions, Delayed Unions and Critical-size Bone Defects. Int. J. Mol. Sci. 2019, 20, 3430. [CrossRef] [PubMed]

8. Goodman, S.B.; Lin, T. Modifying MSC Phenotype to Facilitate Bone Healing: Biological Approaches. Front. Bioeng. Biotechnol. 2020, 8, 641. [CrossRef]

9. Migliorini, F.; Rath, B.; Tingart, M.; Baroncini, A.; Quack, V.; Eschweiler, J. Autogenic mesenchymal stem cells for intervertebral disc regeneration. Int. Orthop. 2019, 43, 1027-1036. [CrossRef] [PubMed]

10. Muthu, S.; Jeyaraman, M.; Gulati, A.; Arora, A. Current evidence on mesenchymal stem cell therapy for traumatic spinal cord injury: Systematic review and meta-analysis. Cytotherapy 2021, 23, 186-197. [CrossRef]

11. Golob, A.L.; Wipf, J.E. Low back pain. Med. Clin. North Am. 2014, 98, 405-428. [CrossRef] [PubMed]

12. Dieleman, J.L.; Squires, E.; Bui, A.L.; Campbell, M.; Chapin, A.; Hamavid, H.; Horst, C.; Li, Z.; Matyasz, T.; Reynolds, A.; et al. Factors Associated With Increases in US Health Care Spending, 1996-2013. JAMA 2017, 318, 1668-1678. [CrossRef] [PubMed]

13. Migliorini, F.; Maffulli, N.; Eschweiler, J.; Betsch, M.; Catalano, G.; Driessen, A.; Tingart, M.; Baroncini, A. The pharmacological management of chronic lower back pain. Expert Opin. Pharmacother. 2021, 22, 109-119. [CrossRef]

14. Baroncini, A.; Maffulli, N.; Eschweiler, J.; Knobe, M.; Tingart, M.; Migliorini, F. Management of facet joints osteoarthritis associated with chronic low back pain: A systematic review. Surgeon 2021. [CrossRef] [PubMed]

15. Migliorini, F.; Maffulli, N.; Eschweiler, J.; Tingart, M.; Baroncini, A. Non-steroidal anti-inflammatory drugs and gabapentinoids for chronic lumbar pain: A Bayesian network meta-analysis of randomized controlled trials. Br. Med. Bull. 2021, 138, 85-95. [CrossRef]

16. Navani, A.; Manchikanti, L.; Albers, S.L.; Latchaw, R.E.; Sanapati, J.; Kaye, A.D.; Atluri, S.; Jordan, S.; Gupta, A.; Cedeno, D.; et al. Responsible, Safe, and Effective Use of Biologics in the Management of Low Back Pain: American Society of Interventional Pain Physicians (ASIPP) Guidelines. Pain Physician 2019, 22, S1-S74.

17. Haufe, S.M.W.; Mork, A.R. Intradiscal injection of hematopoietic stem cells in an attempt to rejuvenate the intervertebral discs. Stem Cells Dev. 2006, 15, 136-137. [CrossRef]

18. Wolff, M.; Shillington, J.M.; Rathbone, C.; Piasecki, S.K.; Barnes, B. Injections of concentrated bone marrow aspirate as treatment for Discogenic pain: A retrospective analysis. BMC Musculoskelet. Disord. 2020, 21, 135. [CrossRef]

19. Pettine, K.A.; Suzuki, R.K.; Sand, T.T.; Murphy, M.B. Autologous bone marrow concentrate intradiscal injection for the treatment of degenerative disc disease with three-year follow-up. Int. Orthop. 2017, 41, 2097-2103. [CrossRef]

20. Kumar, H.; Ha, D.-H.; Lee, E.-J.; Park, J.H.; Shim, J.H.; Ahn, T.-K.; Kim, K.-T.; Ropper, A.E.; Sohn, S.; Kim, C.-H.; et al. Safety and tolerability of intradiscal implantation of combined autologous adipose-derived mesenchymal stem cells and hyaluronic acid in patients with chronic discogenic low back pain: 1-year follow-up of a phase I study. Stem Cell Res. Ther. 2017, 8, 262. [CrossRef]

21. Amirdelfan, K.; Bae, H.; McJunkin, T.; DePalma, M.; Kim, K.; Beckworth, W.J.; Ghiselli, G.; Bainbridge, J.S.; Dryer, R.; Deer, T.R.; et al. Allogeneic mesenchymal precursor cells treatment for chronic low back pain associated with degenerative disc disease: A prospective randomized, placebo-controlled 36-month study of safety and efficacy. Spine J. 2021, 21, 212-230. [CrossRef] [PubMed]

22. Orozco, L.; Soler, R.; Morera, C.; Alberca, M.; Sánchez, A.; García-Sancho, J. Intervertebral disc repair by autologous mesenchymal bone marrow cells: A pilot study. Transplantation 2011, 92, 822-828. [CrossRef]

23. Noriega, D.C.; Ardura, F.; Hernández-Ramajo, R.; Martín-Ferrero, M.Á.; Sánchez-Lite, I.; Toribio, B.; Alberca, M.; García, V.; Moraleda, J.M.; Sánchez, A.; et al. Intervertebral Disc Repair by Allogeneic Mesenchymal Bone Marrow Cells: A Randomized Controlled Trial. Transplantation 2017, 101, 1945-1951. [CrossRef] [PubMed]

24. Elabd, C.; Centeno, C.J.; Schultz, J.R.; Lutz, G.; Ichim, T.; Silva, F.J. Intra-discal injection of autologous, hypoxic cultured bone marrow-derived mesenchymal stem cells in five patients with chronic lower back pain: A long-term safety and feasibility study. $J$. Transl. Med. 2016, 14, 253. [CrossRef]

25. Yoshikawa, T.; Ueda, Y.; Miyazaki, K.; Koizumi, M.; Takakura, Y. Disc regeneration therapy using marrow mesenchymal cell transplantation: A report of two case studies. Spine 2010, 35, E475-E480. [CrossRef]

26. Pettine, K.A.; Murphy, M.B.; Suzuki, R.K.; Sand, T.T. Percutaneous injection of autologous bone marrow concentrate cells significantly reduces lumbar discogenic pain through 12 months. Stem Cells 2015, 33, 146-156. [CrossRef] [PubMed]

27. Singh, V.; McGuffin, S.; Sabo, M.; Nicholls, M. Lumbar Spine Osteomyelitis and Diskitis following Intradiskal Stem Cell Injections. PM R 2020, 12, 624-625. [CrossRef]

28. Vadalà, G.; Sowa, G.; Hubert, M.; Gilbertson, L.G.; Denaro, V.; Kang, J.D. Mesenchymal stem cells injection in degenerated intervertebral disc: Cell leakage may induce osteophyte formation. J. Tissue Eng. Regen. Med. 2012, 6, 348-355. [CrossRef] [PubMed]

29. Amariglio, N.; Hirshberg, A.; Scheithauer, B.W.; Cohen, Y.; Loewenthal, R.; Trakhtenbrot, L.; Paz, N.; Koren-Michowitz, M.; Waldman, D.; Leider-Trejo, L.; et al. Donor-derived brain tumor following neural stem cell transplantation in an ataxia telangiectasia patient. PLoS Med. 2009, 6, e1000029. [CrossRef]

30. Yim, R.L.-H.; Lee, J.T.-Y.; Bow, C.H.; Meij, B.; Leung, V.; Cheung, K.M.C.; Vavken, P.; Samartzis, D. A systematic review of the safety and efficacy of mesenchymal stem cells for disc degeneration: Insights and future directions for regenerative therapeutics. Stem Cells Dev. 2014, 23, 2553-2567. [CrossRef] 
31. Aoun, S.G.; Peinado Reyes, V.; El Ahmadieh, T.Y.; Davies, M.; Patel, A.R.; Ban, V.S.; Plitt, A.; El Tecle, N.E.; Moreno, J.R.; Raisanen, J.; et al. Stem cell injections for axial back pain: A systematic review of associated risks and complications with a case illustration of diffuse hyperplastic gliosis resulting in cauda equina syndrome. J. Neurosurg. Spine 2019, 31, 906-913. [CrossRef]

32. Hurst, R.W.; Bosch, E.P.; Peter Bosch, E.; Morris, J.M.; Dyck, P.J.B.; Reeves, R.K. Inflammatory hypertrophic cauda equina following intrathecal neural stem cell injection. Muscle Nerve 2013, 48, 831-835. [CrossRef] [PubMed]

33. Manchikanti, L.; Centeno, C.J.; Atluri, S.; Albers, S.L.; Shapiro, S.; Malanga, G.A.; Abd-Elsayed, A.; Jerome, M.; Hirsch, J.A.; Kaye, A.D.; et al. Bone Marrow Concentrate (BMC) Therapy in Musculoskeletal Disorders: Evidence-Based Policy Position Statement of American Society of Interventional Pain Physicians (ASIPP). Pain Physician 2020, 23, E85-E131.

34. Baroncini, A.; Maffulli, N.; Eschweiler, J.; Tingart, M.; Migliorini, F. Pharmacological management of secondary spinal cord injury. Expert Opin. Pharmacother. 2021, 1-8. [CrossRef]

35. Donovan, J.; Kirshblum, S. Clinical Trials in Traumatic Spinal Cord Injury. Neurotherapeutics 2018, 15, 654-668. [CrossRef] [PubMed]

36. Hachem, L.D.; Ahuja, C.S.; Fehlings, M.G. Assessment and management of acute spinal cord injury: From point of injury to rehabilitation. J. Spinal Cord Med. 2017, 40, 665-675. [CrossRef]

37. Zhu, L.; Liu, T.; Cai, J.; Ma, J.; Chen, A.-m. Repair and regeneration of lumbosacral nerve defects in rats with chitosan conduits containing bone marrow mesenchymal stem cells. Injury 2015, 46, 2156-2163. [CrossRef] [PubMed]

38. Chopp, M.; Zhang, X.H.; Li, Y.; Wang, L.; Chen, J.; Lu, D.; Lu, M.; Rosenblum, M. Spinal cord injury in rat: Treatment with bone marrow stromal cell transplantation. Neuroreport 2000, 11, 3001-3005. [CrossRef] [PubMed]

39. Khan, S.; Mafi, P.; Mafi, R.; Khan, W. A Systematic Review of Mesenchymal Stem Cells in Spinal Cord Injury, Intervertebral Disc Repair and Spinal Fusion. Curr. Stem Cell Res. Ther. 2018, 13, 316-323. [CrossRef]

40. Zurita, M.; Vaquero, J. Bone marrow stromal cells can achieve cure of chronic paraplegic rats: Functional and morphological outcome one year after transplantation. Neurosci. Lett. 2006, 402, 51-56. [CrossRef] [PubMed]

41. Chen, Y.-B.; Jia, Q.-Z.; Li, D.-J.; Sun, J.-H.; Xi, S.; Liu, L.-P.; Gao, D.-X.; Jiang, D.-W. Spinal cord injury in rats treated using bone marrow mesenchymal stem-cell transplantation. Int. J. Clin. Exp. Med. 2015, 8, 9348-9354.

42. Yousefifard, M.; Nasseri Maleki, S.; Askarian-Amiri, S.; Vaccaro, A.R.; Chapman, J.R.; Fehlings, M.G.; Hosseini, M.; RahimiMovaghar, V. A combination of mesenchymal stem cells and scaffolds promotes motor functional recovery in spinal cord injury: A systematic review and meta-analysis. J. Neurosurg. Spine 2019, 32, 269-284. [CrossRef] [PubMed]

43. Curtis, E.; Martin, J.R.; Gabel, B.; Sidhu, N.; Rzesiewicz, T.K.; Mandeville, R.; van Gorp, S.; Leerink, M.; Tadokoro, T.; Marsala, S.; et al. A First-in-Human, Phase I Study of Neural Stem Cell Transplantation for Chronic Spinal Cord Injury. Cell Stem Cell 2018, 22, 941-950.e6. [CrossRef]

44. Xiao, Z.; Tang, F.; Zhao, Y.; Han, G.; Yin, N.; Li, X.; Chen, B.; Han, S.; Jiang, X.; Yun, C.; et al. Significant Improvement of Acute Complete Spinal Cord Injury Patients Diagnosed by a Combined Criteria Implanted with NeuroRegen Scaffolds and Mesenchymal Stem Cells. Cell Transplant. 2018, 27, 907-915. [CrossRef]

45. Vaquero, J.; Zurita, M.; Rico, M.A.; Aguayo, C.; Bonilla, C.; Marin, E.; Tapiador, N.; Sevilla, M.; Vazquez, D.; Carballido, J.; et al. Intrathecal administration of autologous mesenchymal stromal cells for spinal cord injury: Safety and efficacy of the $100 / 3$ guideline. Cytotherapy 2018, 20, 806-819. [CrossRef]

46. Chotivichit, A.; Ruangchainikom, M.; Chiewvit, P.; Wongkajornsilp, A.; Sujirattanawimol, K. Chronic spinal cord injury treated with transplanted autologous bone marrow-derived mesenchymal stem cells tracked by magnetic resonance imaging: A case report. J. Med. Case Rep. 2015, 9, 79. [CrossRef] [PubMed]

47. Levi, A.D.; Anderson, K.D.; Okonkwo, D.O.; Park, P.; Bryce, T.N.; Kurpad, S.N.; Aarabi, B.; Hsieh, J.; Gant, K. Clinical Outcomes from a Multi-Center Study of Human Neural Stem Cell Transplantation in Chronic Cervical Spinal Cord Injury. J. Neurotrauma 2019, 36, 891-902. [CrossRef]

48. Levi, A.D.; Okonkwo, D.O.; Park, P.; Jenkins, A.L.; Kurpad, S.N.; Parr, A.M.; Ganju, A.; Aarabi, B.; Kim, D.; Casha, S.; et al. Emerging Safety of Intramedullary Transplantation of Human Neural Stem Cells in Chronic Cervical and Thoracic Spinal Cord Injury. Neurosurgery 2018, 82, 562-575. [CrossRef]

49. Law, L.; Hunt, C.L.; van Wijnen, A.J.; Nassr, A.; Larson, A.N.; Eldrige, J.S.; Mauck, W.D.; Pingree, M.J.; Yang, J.; Muir, C.W.; et al. Office-Based Mesenchymal Stem Cell Therapy for the Treatment of Musculoskeletal Disease: A Systematic Review of Recent Human Studies. Pain Med. 2019, 20, 1570-1583. [CrossRef] [PubMed]

50. Piazza, N.; Dehghani, M.; Gaborski, T.R.; Wuertz-Kozak, K. Therapeutic Potential of Extracellular Vesicles in Degenerative Diseases of the Intervertebral Disc. Front. Bioeng. Biotechnol. 2020, 8, 311. [CrossRef] [PubMed]

51. Hofler, R.C.; Swong, K.; Martin, B.; Wemhoff, M.; Jones, G.A. Risk of Pseudoarthrosis after Spinal Fusion: Analysis from the Healthcare Cost and Utilization Project. World Neurosurg. 2018, 120, e194-e202. [CrossRef] [PubMed]

52. Lin, W.; Ha, A.; Boddapati, V.; Yuan, W.; Riew, K.D. Diagnosing Pseudoarthrosis After Anterior Cervical Discectomy and Fusion. Neurospine 2018, 15, 194-205. [CrossRef] [PubMed] 